Chem. Pharm. Bull.

34(10)4287-4293(1986)]

\title{
Effects of Sodium Metallochlorophyllins on the Activity and Components of the Microsomal Drug-Metabolizing Enzyme System in Rat Liver
}

\author{
Kimie Imai, ${ }^{*, a}$ Tachio Aimoto, ${ }^{a}$ Masaki Sato, ${ }^{b}$ Kazuhiro Watanabe, ${ }^{b}$ \\ RYOHEI KIMURA $^{b}$ and TOSHIRO MURATA ${ }^{b}$
}

Faculty of Pharmaceutical Sciences, Setsunan University, ${ }^{a} 45-1$, Nagaotoge-cho, Hirakata, Osaka 573-01, Japan and Shizuoka College of Pharmacy, ${ }^{b}$ 2-2-1, Oshika, Shizuoka 422, Japan

(Received March 24, 1986)

\begin{abstract}
Several sodium metallochlorophyllins (Me-Chl-Na), i.e., sodium copper chlorophyllin (CuChl-Na), sodium cobalt chlorophyllin and sodium iron chlorophyllin, decreased the activities of aminopyrine $N$-demethylase and aniline hydroxylase and the content of cytochrome P-450 in liver microsomes when given intraperitoneally to rats. The lowest levels of these variables were observed $24 \mathrm{~h}$ after dosing. Me-Chl-Na administration did not modify the substrate-induced spectral changes of cytochrome P-450. Of the kinetic parameters studied in aminopyrine $N$-demethylation and aniline hydroxylation, only the $V_{\max }$ values were markedly decreased by $\mathrm{Cu}-\mathrm{Chl}-\mathrm{Na}$, indicating that the enzyme inhibition was non-competitive. Me-Chl-Na also reduced cytochrome $b_{5}$ and total heme contents and NADPH-cytochrome $\mathrm{c}$ reductase activity in microsomes. Preincubation of liver microsomes from control rats with $\mathrm{Cu}-\mathrm{Chl}-\mathrm{Na}$ did not cause any reduction in the aminopyrineand aniline-metabolizing enzyme activities and in the cytochrome P-450 content.

These findings strongly suggest that the decreases in the activities of the hepatic microsomal drug-metabolizing enzyme system caused by $\mathrm{Me}-\mathrm{Chl}-\mathrm{Na}$ are correlated with the reduction in the contents of microsomal cytochromes $\mathrm{P}-450$ and $\mathrm{b}_{5}$, and are brought about by primary action(s) of $\mathrm{Me}-\mathrm{Chl}-\mathrm{Na}$ on the control mechanism of microsomal hemoprotein levels, not by direct action of Me-Chl-Na on the system.
\end{abstract}

Keywords - metallochlorophyllin; drug metabolism; cytochrome P-450; cytochrome $b_{5}$; NADPH-cytochrome c reductase; spectral change; sleeping time; heme; microsome; rat liver

\section{Introduction}

Sodium metallochlorophyllin (Me-Chl-Na) is a derivative of chlorophyll in which the chelated metal, magnesium, is replaced by other metals such as copper, cobalt or iron. Sodium copper chlorophyllin ( $\mathrm{Cu}-\mathrm{Chl}-\mathrm{Na}$ ), which has copper as the chelated metal, was reported to be a mixture of copper chelates of chlorophyll derivatives, ${ }^{1)}$ and is used as a food additive ${ }^{2)}$ and as a gastrointestinal medicine. ${ }^{3)}$ Sodium cobalt chlorophyllin (Co-Chl-Na) and sodium iron chlorophyllin (Fe-Chl-Na) have also been used as hematopoietics. ${ }^{4)}$

In our previous studies, ${ }^{5)} \mathrm{Cu}-\mathrm{Chl}-\mathrm{Na}$ or some substance(s) derived from $\mathrm{Cu}-\mathrm{Chl}-\mathrm{Na}$ was shown to be distributed in liver microsomes when $\mathrm{Cu}-\mathrm{Chl}-\mathrm{Na}$ was given intraperitoneally (i.p.) to rats. Maines and Kappas reported that several porphyrin compounds, closely related to Me-Chl-Na in chemical structure, exerted potent degradative effects in vitro on microsomal cytochromes P-450 and $b_{5}$, heme, and cytochrome P-450-mediated drug oxidation in rat liver, ${ }^{6)}$ and that the administration of cobalt protoporphyrin $\mathrm{IX}^{7)}$ and methemalbumin ${ }^{8)}$ to rats caused decreases in the contents of cytochrome P-450 and heme and in the activity of cytochrome P-450-mediated drug oxidation in liver microsomes.

It was, therefore, of interest to examine the effects of $\mathrm{Me}-\mathrm{Chl}-\mathrm{Na}(\mathrm{Cu}-\mathrm{Chl}-\mathrm{Na}, \mathrm{Co}-\mathrm{Chl}-$ 
$\mathrm{Na}$ and $\mathrm{Fe}-\mathrm{Chl}-\mathrm{Na}$ ), mainly by using $\mathrm{Cu}-\mathrm{Chl}-\mathrm{Na}$, on the activities and contents of components of the hepatic microsomal drug-metabolizing enzyme system in rats. In the present studies, we have demonstrated that all three Me-Chl-Na have inhibitory effects on the activities of aminopyrine $\mathrm{N}$-demethylase, aniline hydroxylase and NADPH-cytochrome c reductase, and cause decreases in the contents of cytochromes P-450 and $b_{5}$ and heme in rat liver microsomes.

\section{Experimental}

Materials - C Cu-Chl-Na was purchased from Wako Pure Chemical Ind., Ltd., Tokyo, Japan. Co-Chl-Na and Fe-Chl-Na were kindly donated by Nampoh Yakuhin Ind., Ltd., Tokyo, Japan. Nicotinamide adenine dinucleotide phosphate (oxidized and reduced forms, $\mathrm{NADP}^{+}$and $\mathrm{NADPH}$, respectively) and nicotinamide adenine dinucleotide (reduced form, NADH) were obtained from Oriental Yeast Co., Ltd., Tokyo, Japan. Glucose 6-phosphate (G6P, disodium salt) and G6P dehydrogenase (G6PDH, from yeast, $350 \mathrm{U} / \mathrm{mg}$ ) were purchased from Boehringer Mannheim Yamanouchi Co., Ltd., Tokyo, Japan. Cytochrome c (from horse heart, Type III) was obtained from Sigma Chemical Co., Ltd., St. Louis, MO, U.S.A. Hexobarbital was purchased from Teikoku Chemical Ind., Ltd., Osaka, Japan. Other chemicals were of reagent grade.

Animal Treatments-Male Wistar rats, weighing approximately $200 \mathrm{~g}$, were used throughout the experiments. They were housed in an air-conditioned room with a commercial chow and tap water ad lib. Each Me-Chl-Na was dissolved in $0.9 \%$ saline, and the resulting solution $(1.0 \mathrm{ml} / 100 \mathrm{~g}$ body weight $)$ was administered i.p. to rats. Control animals received an equivalent volume of the vehicle. All animals were fasted for about $18 \mathrm{~h}$ before sacrifice or administration of hexobarbital, but were allowed free access to water.

Preparation of Microsomes - The animals were killed by decapitation. The livers were removed after perfusion in situ with ice-cold $1.15 \% \mathrm{KCl}$ and homogenized with 2 volumes of ice-cold $1.15 \% \mathrm{KCl}-50 \mathrm{~mm}$ potassium phosphate buffer ( $\dot{\mathrm{pH}}$ 7.4) in a Potter-Elvehjem homogenizer equipped with a Teflon pestle. The homogenate was centrifuged at $9000 \times \boldsymbol{g}$ for $20 \mathrm{~min}$, and the resulting supernatant fraction was centrifuged at $105000 \times \boldsymbol{g}$ for $1 \mathrm{~h}$. The microsomal pellet was suspended in ice-cold $100 \mathrm{~mm}$ potassium phosphate buffer $(\mathrm{pH}$ 7.4). The microsomal protein was determined by the method of Lowry et al. ${ }^{9)}$ Bovine serum albumin was used as a standard.

Enzyme Assay- - Aminopyrine $N$-demethylase and aniline hydroxylase activities were assayed as follows. The reaction mixtures consisted of $3 \mathrm{mg}$ of microsomal protein, $0.5 \mathrm{mM} \mathrm{NADP}^{+}, 5 \mathrm{~mm} \mathrm{G} 6 \mathrm{P}, 0.6 \mathrm{U}$ G6PDH, $5 \mathrm{mM} \mathrm{MgCl}_{2}$, $0.1 \mathrm{~mm}$ ethylenediaminetetraacetic acid (EDTA), $90 \mathrm{~mm} \mathrm{KCl}, 50 \mathrm{~mm}$ potassium phosphate buffer (pH 7.4) and substrate ( $2 \mathrm{mM}$ aminopyrine or $1 \mathrm{~mm}$ aniline) in a final volume of $2.0 \mathrm{ml}$. Incubations were carried out at $37^{\circ} \mathrm{C}$ for $20 \mathrm{~min}$. The amounts of formaldehyde and $p$-aminophenol formed during incubation were determined by the methods of Nash ${ }^{10)}$ and Imai et al. ${ }^{11)}$ respectively. NADPH-cytochrome c reductase activity was measured by the method of Phillips and Langdon. ${ }^{12)}$

Cytochrome Measurement-Microsomal cytochrome P-450 was determined by the method of Omura and Sato, ${ }^{13)}$ and cytochrome $b_{5}$ was measured by using NADH as the reducing agent. ${ }^{14)}$

Sleeping Time-Rats were injected i.p. with hexobarbital sodium $(150 \mathrm{mg} / \mathrm{kg})$. Sleeping time was determined as the time between the loss of righting reflex and its recovery.

Measurement of Substrate-Induced Spectral Changes _- Substrate-induced spectral changes were measured by the method of Schenkman et al. ${ }^{15)}$

Determination of Heme- Microsomal heme content was determined by the method of Matteis. ${ }^{16)}$

\section{Results and Discussion}

The activities of aminopyrine $\mathrm{N}$-demethylase and aniline hydroxylase and the content of cytochrome P-450 in liver microsomes were determined at various time intervals after the i.p. administration of $\mathrm{Cu}-\mathrm{Chl}-\mathrm{Na}$ at a dose of $100 \mathrm{mg} / \mathrm{kg}$ to rats. As shown in Fig. 1, Cu-Chl-Na decreased the enzyme activities and the content of cytochrome P-450. Both enzyme activities began to decrease gradually and reached their lowest levels at $24 \mathrm{~h}$ after dosing. Both enzyme activities had recovered almost to their initial values by $72 \mathrm{~h}$. The effect of $\mathrm{Cu}-\mathrm{Chl}-\mathrm{Na}$ on cytochrome P-450 content was similar to that on the enzyme activities.

In the following experiments, we examined the effects of various doses of $\mathrm{Cu}-\mathrm{Chl}-\mathrm{Na}$ on the activities of aminopyrine $\dot{N}$-demethylase and aniline hydroxylase and on the content of cytochrome P-450. We also examined whether other Me-Chl-Na such as Co-Chl-Na and FeChl-Na have similar effects on the enzyme activities and the cytochrome content. Tables I, II 


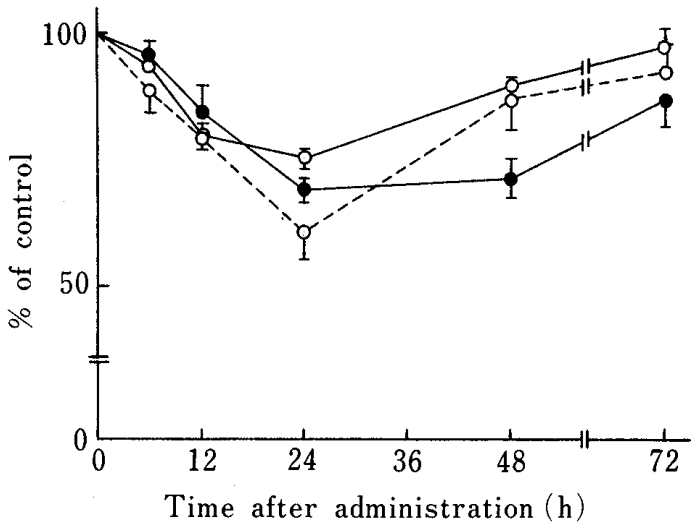

Fig. 1. Time Courses of Drug-Metabolizing Enzyme Activities and Cytochrome P-450 Content in Liver Microsomes of Rats Treated with $\mathrm{Cu}-\mathrm{Chl}-\mathrm{Na}$

Rats were given i.p. Cu-Chl-Na $(100 \mathrm{mg} / \mathrm{kg})$. Each point is expressed as per cent of the control value at the indicated times after administration and represents the mean \pm S.E. for 4 experiments.

- - , aminopyrine $N$-demethylation; --- $\mathrm{O}---$, aniline hydroxylation; - $-\mathrm{O}-$, cytochrome P-450 content.

TABle I. Effect of Me-Chl-Na at Various Dose Levels on Microsomal Aminopyrine $\mathrm{N}$-Demethylase Activity in Rat Liver

\begin{tabular}{|c|c|c|c|c|c|c|}
\hline \multirow{2}{*}{$\begin{array}{c}\text { Me-Chl-Na } \\
\text { treatment } \\
(\mathrm{mg} / \mathrm{kg})\end{array}$} & \multicolumn{2}{|c|}{$\mathrm{Cu}-\mathrm{Chl}-\mathrm{Na}$} & \multicolumn{2}{|c|}{$\mathrm{Co}-\mathrm{Chl}-\mathrm{Na}$} & \multicolumn{2}{|c|}{$\mathrm{Fe}-\mathrm{Ch} l-\mathrm{Na}$} \\
\hline & Activity $^{a}$ & $\begin{array}{c}\text { Dec. } \\
(\%)\end{array}$ & Activity $^{a)}$ & $\begin{array}{c}\text { Dec. } \\
(\%)\end{array}$ & Activity $\left.^{a}\right)$ & $\begin{array}{c}\text { Dec. } \\
(\%)\end{array}$ \\
\hline Control & $91.2 \pm 4.5$ & & $97.6 \pm 1.5$ & & $86.2 \pm 2.0$ & \\
\hline 10 & $89.4 \pm 0.6$ & 2.0 & $92.3 \pm 3.0$ & 5.4 & $77.5 \pm 5.2$ & 10.0 \\
\hline 25 & $75.7 \pm 3.1^{b)}$ & 17.0 & $68.3 \pm 2.1^{b)}$ & 30.0 & $67.6 \pm 2.8^{b}$ & 21.6 \\
\hline 50 & $67.9 \pm 2.8^{b)}$ & 25.5 & $60.4 \pm 2.7^{b)}$ & 38.1 & $63.6 \pm 3.0^{b)}$ & 26.2 \\
\hline 100 & $62.7 \pm 4.1^{b)}$ & 31.3 & $63.8 \pm 3.9^{b)}$ & 34.6 & $59.4 \pm 1.2^{b)}$ & 31.3 \\
\hline
\end{tabular}

Rats were given i.p. Me-Chl-Na at various doses as indicated and sacrificed $24 \mathrm{~h}$ after the injection. Each result is the mean \pm S.E. for $5-7$ rats. a) $\mathrm{nmol} \mathrm{HCHO}$ formed $/ \mathrm{mg}$ protein $/ 20 \mathrm{~min}$. b) Significantly different from the control, $p<0.05$.

TABLE II. Effect of Me-Chl-Na at Various Dose Levels on Microsomal Aniline Hydroxylase Activity in Rat Liver

\begin{tabular}{|c|c|c|c|c|c|c|}
\hline \multirow{2}{*}{$\begin{array}{c}\text { Me-Chl-Na } \\
\text { treatment } \\
(\mathrm{mg} / \mathrm{kg})\end{array}$} & \multicolumn{2}{|c|}{$\mathrm{Cu}-\mathrm{Chl}-\mathrm{Na}$} & \multicolumn{2}{|c|}{$\mathrm{Co}-\mathrm{Chl}-\mathrm{Na}$} & \multicolumn{2}{|c|}{$\mathrm{Fe}-\mathrm{Chl}-\mathrm{Na}$} \\
\hline & Activity $^{a)}$ & $\begin{array}{l}\text { Dec. } \\
(\%)\end{array}$ & Activity $^{a)}$ & $\begin{array}{l}\text { Dec. } \\
(\%)\end{array}$ & Activity ${ }^{a}$ & $\begin{array}{l}\text { Dec. } \\
(\%)\end{array}$ \\
\hline Control & $22.5 \pm 0.4$ & & $22.5 \pm 0.8$ & & $21.5 \pm 1.1$ & \\
\hline 10 & $21.5 \pm 0.6$ & 3.6 & $20.5 \pm 0.9$ & 8.9 & $20.7 \pm 0.7$ & 3.7 \\
\hline 25 & $18.2 \pm 1.0^{b)}$ & 19.1 & $12.4 \pm 0.5^{b)}$ & 44.9 & $16.2 \pm 0.9^{b)}$ & 24.7 \\
\hline 50 & $13.8 \pm 0.4^{b)}$ & 38.7 & $10.4 \pm 0.7^{b)}$ & 53.8 & $13.4 \pm 0.5^{b)}$ & 37.7 \\
\hline 100 & $11.8 \pm 0.4^{b)}$ & 47.6 & $9.2 \pm 0.7^{b)}$ & 59.1 & $9.8 \pm 0.5^{b)}$ & 54.4 \\
\hline
\end{tabular}

Treatment of rats was carried out as described in the legend to Table I. Each result is the mean \pm S.E for 5-7 rats. a) nmol $p$-aminophenol formed $/ \mathrm{mg}$ protein $/ 20 \mathrm{~min} . \quad b)$ Significantly different from the control, $p<0.05$.

and III show the results. All three Me-Chl-Na at doses of $25 \mathrm{mg} / \mathrm{kg}$ or above caused a significant decrease of both aminopyrine $N$-demethylase and aniline hydroxylase activities, and significantly reduced the content of cytochrome P-450. The maximal effects were observed with the dose of $100 \mathrm{mg} / \mathrm{kg}$. Co-Chl-Na showed a relatively high reductive activity among the three Me-Chl-Na examined.

To clarify whether the decrease of the enzyme activities by Me-Chl-Na is ascribed either to an altered affinity of cytochrome P-450 for the enzyme substrates or to the reduction in the 
TABLE III. Effect of Me-Chl-Na at Various Dose Levels on Microsomal Cytochrome P-450 Content in Rat Liver

\begin{tabular}{|c|c|c|c|c|c|c|}
\hline \multirow{2}{*}{$\begin{array}{c}\text { Me-Chl-Na } \\
\text { treatment } \\
(\mathrm{mg} / \mathrm{kg})\end{array}$} & \multicolumn{2}{|l|}{$\mathrm{Cu}-\mathrm{Chl}-\mathrm{Na}$} & \multicolumn{2}{|c|}{$\mathrm{Co}-\mathrm{Chl}-\mathrm{Na}$} & \multicolumn{2}{|l|}{$\mathrm{Fe}-\mathrm{Chl}-\mathrm{Na}$} \\
\hline & Content ${ }^{a)}$ & $\begin{array}{l}\text { Dec. } \\
(\%)\end{array}$ & Content $^{a)}$ & $\begin{array}{c}\text { Dec. } \\
(\%)\end{array}$ & Content $^{a)}$ & $\begin{array}{l}\text { Dec. } \\
(\%)\end{array}$ \\
\hline Control & $1.031 \pm 0.020$ & & $1.090 \pm 0.021$ & & $1.023 \pm 0.017$ & \\
\hline 10 & $0.995 \pm 0.011$ & 3.5 & $1.012 \pm 0.034$ & 7.2 & $0.946 \pm 0.046$ & 7.5 \\
\hline 25 & $0.912 \pm 0.032^{b)}$ & 11.5 & $0.803 \pm 0.017^{b)}$ & 26.3 & $0.860 \pm 0.017^{b)}$ & 15.9 \\
\hline 50 & $0.783 \pm 0.032^{b y}$ & 24.1 & $0.713 \pm 0.015^{b)}$ & 34.6 & $0.806 \pm 0.041^{b)}$ & 21.2 \\
\hline 100 & $\left.0.738 \pm 0.024^{b}\right)$ & 28.4 & $0.710 \pm 0.023^{b)}$ & 34.9 & $0.714 \pm 0.022^{b)}$ & 30.2 \\
\hline
\end{tabular}

Treatment of rats was carried out as described in the legend to Table I. Each result is the mean \pm S.E. for $5-7$ rats. a) $\mathrm{nmol} / \mathrm{mg}$ protein. b) Significantly different from the control, $p<0.05$.

TABLE IV. Effects of Me-Chl-Na Administration on Substrate-Induced Spectral Changes of Cytochrome P-450 in Liver Microsomes of Rats

\begin{tabular}{lccc}
\hline \hline & & \multicolumn{2}{c}{ Spectral change } \\
\cline { 3 - 4 } $\begin{array}{c}\text { Me-Chl-Na } \\
\text { treatment }\end{array}$ & $\begin{array}{c}\text { Dose } \\
\text { (mg/kg) }\end{array}$ & Aminopyrine $^{a)}$ & Aniline $^{b)}$ \\
\hline Control & 50 & $7.8 \pm 0.2$ & $15.4 \pm 0.4$ \\
Cu-Chl-Na & 100 & $7.5 \pm 0.3$ & $14.0 \pm 0.3^{c)}$ \\
& 50 & $7.5 \pm 0.4$ & $14.1 \pm 0.3^{c)}$ \\
Co-Chl-Na & 100 & $7.6 \pm 0.4$ & $14.2 \pm 0.3^{c)}$ \\
& 50 & $7.9 \pm 0.3$ & $15.3 \pm 0.1$ \\
Fe-Chl-Na & 100 & $7.1 \pm 0.2^{c)}$ & $14.0 \pm 0.5$ \\
& & $8.0 \pm 0.4$ & $14.4 \pm 0.4$ \\
\hline
\end{tabular}

Rats were given i.p. Me-Chl-Na and sacrificed $24 \mathrm{~h}$ after the injection. Difference spectra induced with $2 \mathrm{~mm}$ aminopyrine or aniline were determined in the mixture containing $6 \mathrm{mg}$ of microsomal protein, $102.7 \mathrm{mM} \mathrm{KCl}$, and $50 \mathrm{~mm}$ potassium phosphate buffer $(\mathrm{pH} 7.5)$ in a final volume of $3.0 \mathrm{ml}$. Each result is the mean \pm S.E. for $5-7$ rats. a) $\Delta A_{500-421 \mathrm{~nm}} \times 10^{3} / \mathrm{nmol}$ cytochrome.P-450. b) $\Delta A_{431-500 \mathrm{~nm}} \times 10^{3} / \mathrm{nmol}$ cytochrome P-450, c) Significantly different from the control, $p<0.05$.

content of the cytochrome, or to both, we determined the substrate-induced spectral changes of the cytochrome P-450 and carried out a kinetic analysis of aminopyrine $N$-demethylation and aniline hydroxylation in liver microsomes. As shown in Table IV, the Me-Chl-Na tested had little or no effect on the spectral interactions between the microsomal cytochrome P-450 and its substrates, i.e., aminopyrine and aniline. The Lineweaver-Burk plot of aminopyrine $\mathrm{N}$ demethylase activity in liver microsomes from rats killed $24 \mathrm{~h}$ after the administration of a $100 \mathrm{mg} / \mathrm{kg}$ dose of $\mathrm{Cu}-\mathrm{Chl}-\mathrm{Na}$ is depicted in Fig. 2. The enzyme in control hepatic microsomes had two apparent $K_{\mathrm{m}}$ values $(0.54$ and $1.63 \mathrm{~mm})$ toward aminopyrine, in accordance with the findings reported by Pederson and Aust, ${ }^{17)}$ and Aust and Stevens. ${ }^{18)}$ The enzyme in microsomes from rats treated with $\mathrm{Cu}-\mathrm{Chl}-\mathrm{Na}$ also had two apparent $K_{\mathrm{m}}$ values $(0.51$ and $1.47 \mathrm{mM}$ ), which were almost the same as those of the control, whereas the $V_{\max }$ values were much lower in microsomes from the $\mathrm{Cu}-\mathrm{Chl}-\mathrm{Na}$-treated rats $(88$ and $126 \mathrm{nmol} \mathrm{HCHO}$ formed $/ \mathrm{mg}$ protein $/ 20 \mathrm{~min}$ ) than in those from control rats (125 and $184 \mathrm{nmol} \mathrm{HCHO}$ formed $/ \mathrm{mg}$ protein $/ 20 \mathrm{~min}$ ). These results indicate that the inhibition of aminopyrine $\mathrm{N}$ demethylation is non-competitive. In the case of aniline hydroxylase, we observed one $K_{\mathrm{m}}$ value and one $V_{\max }$ value for the aniline hydroxylation in microsomes both from control and from treated rats, in contrast to the case of aminopyrine $N$-demethylation, when the substrate was used at concentrations of 0.05 to $0.2 \mathrm{~mm}$. The inhibition of aniline hydroxylase caused by 
TABLE V. Effects of Me-Chl-Na Administration on Content of Cytochrome $b_{5}$ and Activity of NADPH-Cytochrome c Reductase in Rat Liver Microsomes

\begin{tabular}{|c|c|c|c|c|c|}
\hline \multirow{2}{*}{$\begin{array}{c}\mathrm{Me}-\mathrm{Chl}-\mathrm{Na} \\
\text { treatment }\end{array}$} & \multirow{2}{*}{$\begin{array}{c}\text { Dose } \\
(\mathrm{mg} / \mathrm{kg})\end{array}$} & \multicolumn{2}{|c|}{ Cytochrome $b_{5}$} & \multicolumn{2}{|c|}{$\begin{array}{c}\text { NADPH-cytochrome c } \\
\text { reductase }\end{array}$} \\
\hline & & Content $^{a)}$ & $\begin{array}{l}\text { Dec. } \\
(\%)\end{array}$ & Activity $^{b)}$ & $\begin{array}{l}\text { Dec. } \\
(\%)\end{array}$ \\
\hline Control & & $0.528 \pm 0.012$ & & $79.1 \pm 2.1$ & \\
\hline \multirow[t]{2}{*}{$\mathrm{Cu}-\mathrm{Chl}-\mathrm{Na}$} & 50 & $0.475 \pm 0.018^{c)}$ & 10.0 & $70.1 \pm 1.7^{c)}$ & 11.4 \\
\hline & 100 & $0.443 \pm 0.014^{c)}$ & 16.1 & $65.9 \pm 1.7^{c)}$ & 16.7 \\
\hline \multirow[t]{2}{*}{$\mathrm{Co}-\mathrm{Chl}-\mathrm{Na}$} & 50 & $0.414 \pm 0.018^{c)}$ & 21.6 & $63.5 \pm 0.4^{c)}$ & 19.7 \\
\hline & 100 & $0.414 \pm 0.018^{c)}$ & 21.6 & $63.5 \pm 2.2^{c)}$ & 19.7 \\
\hline \multirow[t]{2}{*}{$\mathrm{Fe}-\mathrm{Chl}-\mathrm{Na}$} & 50 & $0.450 \pm 0.013^{c)}$ & 14.8 & $68.1 \pm 2.4^{c)}$ & 13.9 \\
\hline & 100 & $0.427 \pm 0.019^{c)}$ & 19.1 & $67.5 \pm 1.6^{c)}$ & 14.7 \\
\hline
\end{tabular}

Treatment of rats was carried out as described in the footnote to Table IV. Each result is the mean + S.E. for 5-6 rats. a) nmol/mg protein. b) nmol cytochrome c reduced $/ \mathrm{mg}$ protein $/ \mathrm{min}$. c) Significantly different from the control, $p<0.05$.

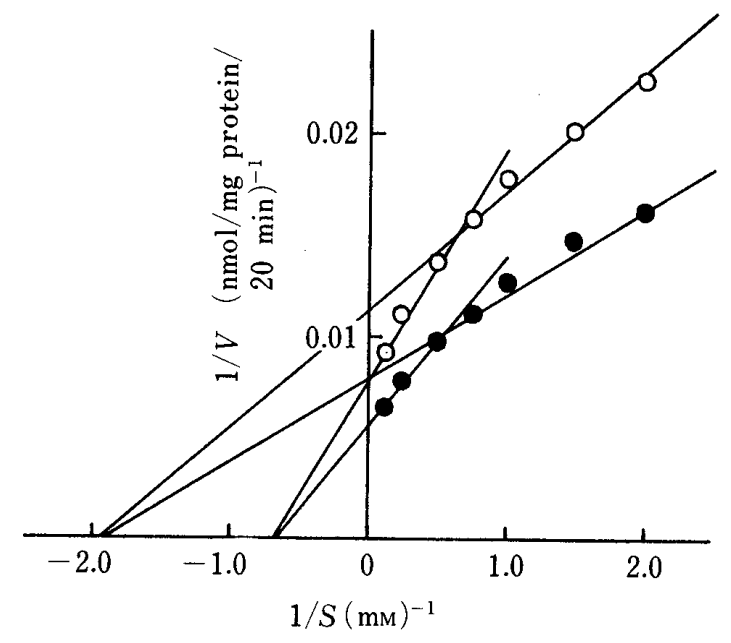

Fig. 2. Lineweaver-Burk Plot of Aminopyrine $N$-Demethylation in Liver Microsomes from $\mathrm{Cu}-\mathrm{Chl}$-Na-treated Rats

Rats were treated with $\mathrm{Cu}-\mathrm{Chl}-\mathrm{Na}(100 \mathrm{mg} / \mathrm{kg}$, i.p.) and sacrificed $24 \mathrm{~h}$ after the injection. Each point represents the mean of 2 groups of 3 rats.

- - , control; - O-, Cu-Chl-Na-treated.
TABlE VI. Effect of Cu-Chl-Na Administration on Hexobarbital Sleeping Time in Rats

\begin{tabular}{ccc}
\hline \hline $\begin{array}{c}\text { Cu-Chl-Na } \\
\text { treatment } \\
(\mathrm{mg} / \mathrm{kg})\end{array}$ & $\begin{array}{c}\text { Sleeping time } \\
(\mathrm{min})\end{array}$ & $\%$ \\
\hline Control & $30.3 \pm 1.4$ & 100 \\
50 & $40.4 \pm 0.9^{a)}$ & 133 \\
100 & $42.7 \pm 2.1^{a)}$ & 141 \\
\hline
\end{tabular}

Twenty-four hours after i.p. administration of $\mathrm{Cu}-\mathrm{Chl}-\mathrm{Na}$ rats were given i.p. hexobarbital (sodium salt, $150 \mathrm{mg} / \mathrm{kg}$ ). Each result is the mean \pm S.E. for $6-7$ rats. a) Significantly different from the control, $p<0.05$.

$\mathrm{Cu}-\mathrm{Chl}-\mathrm{Na}$ treatment was also non-competitive: the $K_{\mathrm{m}}$ values for the control and treated rat liver microsomes were 0.035 and $0.037 \mathrm{~mm}$, respectively, and the $V_{\max }$ values for the control and treated rat liver microsomes were 18.2 and $9.9 \mathrm{nmol} p$-aminophenol formed $/ \mathrm{mg}$ protein $/ 20 \mathrm{~min}$, respectively. These findings indicate that the decreases in oxidative drugmetabolizing enzyme activities in liver microsomes caused by Me-Chl-Na treatment might be mainly associated with a reduction in the content of cytochrome P-450, but not with a change in the affinity of the cytochrome for its substrates. In the case of aniline hydroxylation, the specific activities, when expressed as activities per nmol cytochrome P-450, were somewhat reduced by Me-Chl-Na-treatment ( $c f$. Tables II and III). This may be due to a decrease of the cytochrome $\mathrm{P}-450$ species responsible for the metabolism of aniline by Me-Chl-Na treatment.

We also examined the effects of the three Me-Chl-Na on the content of another microsomal hemoprotein, cytochrome $b_{5}$, and on the activity of another microsomal enzyme, 
NADPH-cytochrome $\mathrm{c}$ reductase, of the hepatic drug-metabolizing enzyme system. As shown in Table $\mathrm{V}$, all three Me-Chl-Na reduced the cytochrome $b_{5}$ content, though the extent of reduction was less than that of the reduction in cytochrome P-450 content (Table III), and inhibited, though to a minor extent, the reductase activity. These results indicate that $\mathrm{Me}-\mathrm{Chl}-$ $\mathrm{Na}$ might have an inhibitory effect and a lowering effect on the activities and components, respectively, of the microsomal drug-metabolizing enzyme system in the liver when given to rats.

Table VI shows the effect of pretreatment of rats with $\mathrm{Cu}-\mathrm{Chl}-\mathrm{Na}$ on the hexobarbitalinduced sleeping time. $\mathrm{Cu}-\mathrm{Chl}-\mathrm{Na}$ at doses of 50 and $100 \mathrm{mg} / \mathrm{kg}$ caused a significant prolongation of sleeping time. This is thought to be mainly a reflection of the inhibition by $\mathrm{Cu}-\mathrm{Chl}-\mathrm{Na}$ of the activities of the hepatic drug-metabolizing enzyme system by which the barbiturate is metabolized to pharmacologically inactive metabolites, not to an alteration in the action mechanism of the drug in the central nervous system. This may be further supported by the finding that neither trisodium copper chlorin $\mathrm{e}_{6}$ nor disodium copper isochlorin $\mathrm{e}_{4}$, constituents of $\mathrm{Cu}-\mathrm{Chl}-\mathrm{Na},{ }^{19)}$ penetrated the brain in rats when given i.p. ${ }^{20}$ )

In the following experiments, liver microsomes from rats receiving no $\mathrm{Cu}-\mathrm{Chl}-\mathrm{Na}$ were preincubated with $\mathrm{Cu}-\mathrm{Chl}-\mathrm{Na}$ to observe the in vitro effects of $\mathrm{Cu}-\mathrm{Chl}-\mathrm{Na}$ on the activities of aminopyrine $N$-demethylase and aniline hydroxylase and on the content of cytochrome P-450. The content of $\mathrm{Cu}-\mathrm{Chl}-\mathrm{Na}$ in liver microsomes from rats $24 \mathrm{~h}$ after the i.p. injection of a $100 \mathrm{mg} / \mathrm{kg}$ dose of $\mathrm{Cu}-\mathrm{Chl}-\mathrm{Na}$ was $0.514 \pm 0.017 \mu \mathrm{g}$ eq to $\mathrm{Cu}-\mathrm{Chl}-\mathrm{Na} / \mathrm{mg}$ protein, as measured by the method of Sato et al. ${ }^{5)}$ As the content can be calculated to be approximately equivalent

TABLE VII. Effects of Preincubation of Rat Liver Microsomes with $\mathrm{Cu}-\mathrm{Chl}-\mathrm{Na}$ on Drug-Metabolizing Enzyme Activities and Content of Cytochrome P-450

\begin{tabular}{cccc}
\hline $\begin{array}{c}\text { Concn. of } \\
\mathrm{Cu}-\mathrm{Chl}-\mathrm{Na} \\
(\%, \mathrm{w} / \mathrm{v})\end{array}$ & $\begin{array}{c}\text { Aminopyrine } \\
N \text {-demethylase }^{a)}\end{array}$ & $\begin{array}{c}\text { Aniline } \\
\text { hydroxylase }^{b)}\end{array}$ & $\begin{array}{c}\text { Cytochrome P-450 } \\
\text { content }^{c}\end{array}$ \\
\hline 0 & $105.4 \pm 3.1$ & $17.3 \pm 0.4$ & $1.053 \pm 0.009$ \\
$0.15 \times 10^{-3}$ & $106.6 \pm 3.4$ & $17.5 \pm 0.4$ & - \\
$0.3 \times 10^{-3}$ & $109.1 \pm 4.0$ & $17.5 \pm 0.3$ & $0.999 \pm 0.009$ \\
$0.5 \times 10^{-3}$ & $109.4 \pm 3.2$ & $17.5 \pm 0.4$ & $0.991 \pm 0.005$ \\
$1.0 \times 10^{-3}$ & $109.3 \pm 3.6$ & $17.4 \pm 0.4$ & 0.4 \\
\hline
\end{tabular}

After the preincubation $\left(37^{\circ} \mathrm{C}, 30 \mathrm{~min}\right)$ of microsomes $(3 \mathrm{mg}$ protein $/ \mathrm{ml})$ with $\mathrm{Cu}-\mathrm{Chl}-\mathrm{Na}$ at various final concentrations as indicated, the enzyme activities and cytochrome P-450 content were determined. Each result is the mean \pm S.E. for 3 experiments. a) nmol HCHO formed $/ \mathrm{mg}$ protein $/ 20 \mathrm{~min}$. b) nmol $p$ aminophenol formed $/ \mathrm{mg}$ protein $/ 20 \mathrm{~min}$. c) $\mathrm{nmol} / \mathrm{mg}$ protein.

TABle VIII. Effect of Me-Chl-Na at Various Dose Levels on Heme Content in Rat Liver Microsomes

\begin{tabular}{|c|c|c|c|c|c|c|}
\hline \multirow{2}{*}{$\begin{array}{c}\mathrm{Me}-\mathrm{Chl}-\mathrm{Na} \\
\text { treatment } \\
(\mathrm{mg} / \mathrm{kg})\end{array}$} & \multicolumn{2}{|l|}{$\mathrm{Cu}-\mathrm{Chl}-\mathrm{Na}$} & \multicolumn{2}{|c|}{$\mathrm{Co}-\mathrm{Chl}-\mathrm{Na}$} & \multicolumn{2}{|l|}{$\mathrm{Fe}-\mathrm{Chl}-\mathrm{Na}$} \\
\hline & Content $t^{a}$ & $\begin{array}{l}\text { Dec. } \\
(\%)\end{array}$ & Content $^{a)}$ & $\begin{array}{l}\text { Dec. } \\
(\%)\end{array}$ & Content $^{a)}$ & $\begin{array}{l}\text { Dec. } \\
(\%)\end{array}$ \\
\hline Control & $1.704 \pm 0.026$ & & $1.749 \pm 0.046$ & & $1.664 \pm 0.015$ & \\
\hline 10 & $1.654 \pm 0.020$ & 2.9 & $1.629 \pm 0.039$ & 6.9 & $1.626 \pm 0.024$ & 2.3 \\
\hline 25 & $1.544 \pm 0.047^{b)}$ & 9.4 & $1.359 \pm 0.029^{b)}$ & 22.3 & $1.443 \pm 0.025^{b)}$ & 13.3 \\
\hline 50 & $1.402 \pm 0.054^{b)}$ & 17.7 & $1.255 \pm 0.033^{b)}$ & 28.2 & $1.375 \pm 0.086^{b)}$ & 17.4 \\
\hline 100 & $1.324 \pm 0.055^{b)}$ & 22.3 & $1.259 \pm 0.026^{b)}$ & 28.0 & $1.242 \pm 0.033^{b)}$ & 25.4 \\
\hline
\end{tabular}

Treatment of rats was carried out as described in the footnote to Table I. Each result is the mean \pm S.E. for $5-7 \mathrm{rats}$. a) $\mathrm{nmol} / \mathrm{mg}$ protein. b) Significantly different from the control, $p<0.05$. 
to $0.17 \times 10^{-30} \%(\mathrm{w} / \mathrm{v})$ or $2.5 \mu \mathrm{M}$, the concentrations ranging from $0.15 \times 10^{-3}$ to $1.0 \times 10^{-3 \%} \%$ $(\mathrm{w} / \mathrm{v})$ of $\mathrm{Cu}-\mathrm{Chl}-\mathrm{Na}$ used in the present study were approximately equal to or higher than those observed in in vivo experiments. As shown in Table VII, preincubation of the microsomes with various concentrations of $\mathrm{Cu}-\mathrm{Chl}-\mathrm{Na}$ did not cause any alteration in the enzyme activities and cytochrome content. This result suggests that the reduction of enzyme activities and cytochrome content in hepatic microsomal drug-metabolizing enzyme system is not brought about by degradation of cytochrome P-450 itself by Me-Chl-Na.

Considering the findings with porphyrin compounds reported by Maines and Kappas, ${ }^{6-8)}$ it can be assumed that the decrease in the content of microsomal cytochromes by $\mathrm{Me}-\mathrm{Chl}-\mathrm{Na}$ administration is associated with an alteration in the content of protoheme as their prosthetic group. Thus, we measured the total heme content in liver microsomes from rats killed $24 \mathrm{~h}$ after the administration of Me-Chl-Na. Table VIII shows the results. The total heme content exceeded the summed contents of the two microsomal hemoproteins, cytochromes P-450 (Table III) and $b_{5}$ (Table V), in control rat liver microsomes in accordance with the results reported by Maines and Kappas. ${ }^{6}$. Significant reductions in the heme contents were observed with doses of $25 \mathrm{mg} / \mathrm{kg}$ or above of any of the three Me-Chl-Na. The maximal effect was found at the doses of 50 and $100 \mathrm{mg} / \mathrm{kg}$ of Co-Chl-Na, which caused about $28 \%$ decrease in heme content. Co-Chl-Na showed relatively high activity among the three $\mathrm{Me}-$ $\mathrm{Chl}$-Na. These results were similar to those in the experiment to determine the effects on the cytochrome P-450 content (Table III). The reduction in total heme content seems to be associated with a reduction in the contents of the two hemoproteins but not with a reduction in the content of heme fraction except the hemoproteins in microsomes ( $c f$. Tables III and V).

Our present results strongly suggest that the decreases in the activities of the hepatic microsomal drug-metabolizing enzyme system caused by Me-Chl-Na are brought about by primary actions of $\mathrm{Me}-\mathrm{Chl}-\mathrm{Na}$ on the control mechanism of microsomal hemoprotein levels. The mechanisms by which liver microsomal hemoproteins are decreased by Me-Chl-Na remain to be elucidated and are under investigation in our laboratories.

Acknowledgement We are grateful to Toshiko Kuwana and Yoshiji Ohno for their excellent technical assistance.

\section{References and Notes}

1) M. Strell, A. Kalojanoff and F. Zuther, Arzneim.-Forsch., 5, 640 (1955); idem, ibid., 6, 8 (1956); K. Yamamoto and S. Tomura, Rika Gaku Kenkyusho Hokoku, 36, 562 (1960).

2) "Japanese Standards of Food Additives IV," ed. by the Ministry of Health and Welfare, Tokyo, 1978, p. 295.

3) "Drugs in Japan (Ethical Drugs) 10th Ed.," ed. by Japan Pharmaceutical Information Center, Yakugyo Jiho Co., Tokyo, 1986, p. 471.

4) N. Kasugai, Yakkyoku, 23, 445 (1972).

5) M. Sato, K. Imai, R. Kimura and T. Murata, Chem. Pharm. Bull., 32, 716 (1984).

6) M. D. Maines and A. Kappas, J. Biol. Chem., 250, 2363 (1975).

7) M. D. Maines and A. Kappas, J. Biol. Chem., 250, 4171 (1975).

8) M. D. Maines and A. Kappas, Proc. Natl. Acad. Sci. U.S.A., 71, 4293 (1974).

9) O. H. Lowry, N. J. Rosebrough, A. L. Farr and R. J. Randall, J. Biol. Chem., 193, 265 (1951).

10) T. Nash, J. Biol. Chem., 55, 416 (1953).

11) Y. Imai, A. Ito and R. Sato, J. Biochem. (Tokyo), 60, 417 (1966).

12) A. H. Phillips and R. G. Langdon, J. Biol. Chem., 237, 2652 (1962).

13) T. Omura and R. Sato, J. Biol. Chem., 239, 2370 (1964).

14) T. Omura and R. Sato, J. Biol. Chem., 239, 2379 (1964).

15) J. B. Schenkman, H. Remmer and R. W. Estabrook, Mol. Pharmacol., 3, 113 (1967).

16) F. D. Matteis, Biochem. J., 124, 767 (1971).

17) T. C. Pederson and S. D. Aust, Biochem. Pharmacol., 19, 2221 (1970).

18) S. D. Aust and J. B. Stevens, Biochem. Pharmacol., 20, 1061 (1971).

19) M. Sato, I. Fujimoto, T. Sakai, T. Aimoto, R. Kimura and T. Murata, Chem. Pharm. Bull., 34, 2428 (1986).

20) T. Sakai, M. Sato, R. Kimura, T. Murata and T. Aimoto, Abstracts of Papers, The 106th Annual Meeting of the Pharmaceutical Society of Japan, Chiba, April 1986, p. 751. 